\title{
MEASURING THE RISK OF LENDING TO SMALL AND MEDIUM-SIZED ENTERPRISES IN THE REPUBLIC OF SERBIA IN LIGHT OF MODERN BANKING REGULATIONS
}

\author{
Mirela Mitrasevic ${ }^{*}$ and Snezana Bardarova ${ }^{2}$ \\ ${ }^{1}$ Faculty of Business Economics, Bijeljina, University of East Sarajevo, Bosnia and Herzegovina \\ ${ }^{2}$ Faculty of Tourism and Business logistics, Gevgelija, University Coce Delcev, Stip, Republic of \\ North Macedonia
}

\begin{abstract}
The subject matter of this paper is measuring the risk of lending to Small and Medium-sized Enterprises (SMEs) from the point of view of the existing banking regulations. The paper starts from the hypothesis that an increase in the transparency of the credit risk measurement process would enable the timely detection of problems and leave room for the actions necessary for the management of small and mediumsized enterprises, as well as all creditors, and generate an opportunity for SMEs to provide more favorable sources of financing. In the research study, the well-known Altman Z-Score model was used to assess the probability of default and rank a company. The results of the application of the Z-Score model indicate that, to a certain extent, they can detect the companies in which bankruptcy may occur in the two years following the assessment, on the one hand, but they cannot be considered as reliable for the assessment of the probability of the bankruptcy of SMEs in the Republic of Serbia, on the other.
\end{abstract}

Keywords: SME financing, credit risk, capital requirements, credit scoring, bond rating equivalent

JEL Classification: G21, G28

\section{INTRODUCTION}

Small and Medium-sized Enterprises (SMEs) represent the most efficient segment of the economy in almost all countries of the world. These companies

* Correspondence to: M. Mitrasevic, Faculty of Business Economics, Semberskih ratara, 76300 Bijeljina, University of East Sarajevo, Bosnia and Herzegovina; e-mail: mirela.mitrasevic@fpe.ues.rs.ba usually face limited access to the favorable sources of financing in both the money market and the capital market, especially in terms of the conditions and price of their use. It is precisely the difficult financing that is the biggest obstacle to the growth and development of SMEs. As SMEs usually have no access to organized capital markets, bank financing often remains the only alternative. Banks' biggest problems when granting loans to SMEs are related to 
a lack of adequate loan collateral and the unfavorable credit rating of companies, which increases credit risk and requires that these loans, with long and expensive claim processing procedures, should be offered at high interest rates.

The subject matter of this paper is to measure the risk of lending to SMEs from the aspect of the existing banking regulations.

The main goal of the research is to examine, on the example of the SMEs operating on the territory of the Republic of Serbia (RS), the extent to which the wellknown Altman Z-Score model can be considered reliable for the purpose of assessing the probability of default. The paper uses the methodological approach of linking Z-score results with the equivalent of bond ratings, which allows us to determine the probabilities of default in a transparent way.

Our research is based on the following hypothesis:

$\mathrm{H}$ : Increasing the transparency of the credit risk measurement process would allow for the timely detection of problems and leave room for the actions necessary for the management of SMEs, as well as all creditors, and generate an opportunity for SMEs to provide more favorable sources of financing.

The paper is divided into four parts. The first part of the paper emphasizes the role of banks in financing small and medium-sized enterprises. The second part of the paper is focused on calculating capital requirements when using an advanced approach based on internal rating. In the third part of the paper, the way how credit scoring models can be used to assess the probability of default is presented. In the fourth part of the paper, the example of the companies registered for the production of cocoa, chocolate and confectionery products is examined, and whether Z-score models can be considered as reliable for assessing the probability of the bankruptcy of the small and medium-sized enterprises operating in $\mathrm{RS}$ in the observed period is investigated. Also, the extent to which the allocation of SMEs in the category of exposure to individuals affects capital adequacy requirements is shown.

\section{THE ROLE OF BANKS IN FINANCING SMALL AND MEDIUM-SIZED ENTERPRISES}

Financing is a significant factor determining the survival and growth of SMEs. SMEs usually face limited access to favorable sources of financing in both the money market and the capital market, especially in terms of the conditions of and the price for their use (Erić, Beraha, Đuričin, Kecman i Jakišić, 2012, 64). The availability of different sources of financing changes during the lifecycle of a company, depending on the stage of its growth, goals and growth potential, the sector in which the company operates and the relationship of management to risk. The range of possible sources of financing largely depends on the degree of economic development, especially the development of the financial system and financial markets (Erić, 2003). Developed systems are those that have developed the mechanisms of the so-called indirect financing (Mishkin \& Eakins, 2006), where there are several financial institutions and intermediaries.

Difficult financing is the biggest obstacle to the growth and development of SMEs. Therefore, a particular problem for entrepreneurs and SME owners is to provide sources for financing their investments, especially so for innovation, research and development.

Bank loans are the most important source of external financing during the lifetime of the largest number of SMEs. There are various bank loans that can be shortand long-term from the aspect of their maturity, with either a fixed or a variable interest rate. Loans can also be divided according to the purpose, the method of security, the method of repayment, and so on. For the SME sector, when very small businesses are started or run, a microcredit is the most suitable.

Each bank defines the loan offer and the manner of their approval is in accordance with its internal regulations and procedures. In order for SMEs to receive a loan, they must submit a loan application, from which the bank should consider the credit potential of the company and determine the 
company's ability to repay the borrowed funds within the prescribed period. In order to protect the bank from credit risk, it often asks for various additional security mechanisms, such as mortgages, guarantors, and so forth. This is a big problem for SME owners in the initial stages of the lifecycle of a company, because these are young and small businesses without a credit history of a sufficient quality or the adequate payment security instruments that qualify them for loan approval.

Lending conditions for SMEs vary from country to country, but they are always less favorable than those under which large companies borrow. The reasons for this lie in the fact that the credit needs of these two groups of companies are very different, i.e. the fact that smaller loan amounts granted to SMEs necessarily require higher interest rates in order for banks to provide the desired profitability.

The biggest problems banks are faced with when granting loans to SMEs are related to:

- the problem of securing a loan, i.e. an insufficient financial capacity (inadequate cashflow, insufficiently capitalized companies, i.e. a low share of own funds, the high competition that affects a decline in profit margins, high refinancing risk),

- a lack of adequate collateral,

- owner and management risk (i.e. a lack of an adequate corporate governance system),

- a lack of quality business plans,

- a lack of a credit history, and

- the unfavorable credit rating of the company.

The biggest problems SMEs are faced with when using bank loans as a source of financing are:

- high interest rates,

- limited loan amounts, which often do not meet the needs of the project being financed,

- inflexibility,

- long, complicated and expensive loan processing and approval procedures, and

- problematic collateral.
A survey conducted by the auditing and consulting company EY (2019) indicates the problems related to financing the operations of SMEs. Namely, as many as 77 percent of the respondents pointed out the fact that they financed the business and development of their companies from their own funds. Although, in addition to their own funds, which are absolutely at the forefront of financing fast-growing entrepreneurial companies, banks represent the leading source of credits for SMEs, their services are not used to the extent that could be expected given their market dominance. Banks are still not exposed to the risk of lending to small businesses. Many do not either recognize the fact that small portfolios can be of a high quality and are concerned about transaction costs, as these two factors greatly affect return on investment in a situation where there are strong pressures to make a profit and preserve capital.

Undoubtedly, bank loans are a very expensive and limited source of financing for the SME sector in the Republic of Serbia. Restrictions on the granting of bank loans are related to macroeconomic and financial developments in the country, where long-term sources of funds for banks themselves are quite limited, which is why there is particularly a lack of long-term loans. The restrictive credit and monetary policy that has continuously been implemented in RS in the last ten years with a high level of required reserves reduces the credit potential of banks and limits their lending to the SME sector. In addition, one of the reasons for the reduced interest in financing SMEs is the choice of the quality government securities that offer relatively high, but unlike placement in the SME sector, secure earnings.

Given the high degree of uncertainty regarding the business results of SMEs, banks face credit risk, i.e. the probability that the borrower will not be able to repay the borrowed funds within the defined repayment schedule. Since the capital requirements in terms of credit risk have an impact on the price at which banks are willing to lend to SMEs, the methodological aspect of capital calculation in accordance with the Basel standards will be presented in the next part of the paper. 


\section{CAPITAL REQUIREMENTS FOR CREDIT RISK EXPOSURE TO SMALL AND MEDIUM-SIZED ENTERPRISES}

According to the existing banking regulations, a bank may use the standardized approach and the Internal Rating-Based approach (IRB) in order to calculate a capital requirement for the credit risk related to its exposure to SMEs. In addition, the calculation of the capital requirement differs depending on whether the bank classifies the exposure to small and mediumsized enterprises in the category of exposure to companies or exposure to natural persons.

In the standardized approach, banks must classify their exposures according to different risk categories and determine the weights based on the credit rating that the small and medium enterprise received from the external credit assessment institution that received the consent of the National Bank of Serbia. The selection of a rating agency and the use of credit ratings to assign credit risk weights are regulated by the Decision on the Capital Adequacy of the Bank (Official Gazette of the RoS, no. 46/2011, 6/2013 and 51/2014). At the time of writing, Moody's Investor Service Ltd. was on the list of eligible rating agencies (NBS, 2020).

In the approach based on internal rating, banks use internal rating systems when calculating capital requirements for credit risk. There are two variants of the internal ratings approach:

- the basic approach based on internal rating (IRB FIRB), within the framework of which banks use their own estimates of the probability of default $(\mathrm{PD})$, whereas the values of other parameters, i.e. risk components (LGD - loss due to default, $\mathrm{EAD}$ - current exposure arrears, and $\mathrm{M}$ - effective maturity), are determined by the supervisor.

- the advanced IRB approach based on which banks use their own estimates for all risk components, as well as conversion factors, while meeting the minimum standards and, if applicable, their own estimates of effective maturity.

In the next part of the paper, the focus is on the formulas used to calculate capital requirements when using the AIRB approach. Under this approach, a regulatory capital charge is designed to cover a bank's unexpected credit loss, which is denoted as the difference between Value-at-Risk (VaR) at a confidence level of $99.9 \%$ as a measure of a potential portfolio loss over time and the expected loss (Hurlin, Leymarie \& Patin, 2018).

For all SMEs, risk-weighted assets are determined as follows:

Risk value assets $=K \cdot 12.5 \cdot E A D$

where:

$K$ is the capital requirement for credit risk, and $E A D$ is exposure at default.

In the event that an SME, which is not in the default status, is classified into the category of exposure to natural persons (SME Other Retail), the capital requirement for credit risk $(K)$ depends on the assessment of the probability of the occurrence of the default status (the probability of default $(P D)$, a loss given default $(L G D)$, and exposure at default $(E A D)$; and in case SME is classified into the category of exposure to companies (SME Corporate), it also depends on the effective maturity $(M)$ for the given exposure.

In accordance with Basel II, if an SME is classified into the category of exposure to natural persons, a capital requirement for credit risk $(K)$ is determined based on the following formula:

$K=\left\langle L G D^{*} \mathrm{~N}\left[\frac{G(\mathrm{PD})+\sqrt{R} \cdot G(0.999)}{\sqrt{1-R}}\right]-P D \cdot L G D\right\rangle \cdot 1.06(2)$

where:

$N(x)$ stands for the function of the cumulative probability distribution for the standard normal random variable,

$G(Z)$ is the inverse function of the cumulative probability distribution for the standard normal random variable,

$L G D=1-R R$ denotes the loss given default,

$R R$ is the recovery rate, and 
$R$ is the correlation for exposures to individuals:

$$
R=0.03 \cdot \frac{1-e^{-35 \cdot P D}}{1-e^{-35}}+0.16 \cdot\left(1-\frac{1-e^{-35 \cdot P D}}{1-e^{-35}}\right)
$$

If an SME is classified into the category of exposure to companies, a capital requirement for credit risk $(K)$ is determined as follows:

$$
\begin{aligned}
& K=\left\langle L G D^{*} \mathrm{~N}\left[\frac{G(\mathrm{PD})+\sqrt{R \cdot} \cdot G(0.999)}{\sqrt{1-R}}\right]-P D \cdot L G D\right\rangle \\
& \left\langle\frac{1+(M-2.5) \cdot b}{1-1.5 \cdot b}\right\rangle \cdot 1.06
\end{aligned}
$$

$$
b=[0.11852-0.05478 \cdot \ln (P D)]^{2},
$$

where:

$R$ is the correlation for exposures to companies:

$$
\begin{aligned}
& R=0.12 \cdot \frac{1-e^{-50 \cdot P D}}{1-e^{-50}}+0.24 \cdot\left(1-\frac{1-e^{-50 \cdot P D}}{1-e^{-50}}\right)- \\
& -0.04 \cdot\left(1-\frac{(S-5)}{45}\right)
\end{aligned}
$$

For exposures to small and medium-sized enterprises, i.e. the companies belonging to the group whose total annual income $(S)$ at the consolidated level is less than or equal to EUR 50 million in the dinar equivalent, the expression $0.04 *[1-(S-5) / 45]$, is added when calculating the correlation, where 5 million euros $\leq \mathrm{S}$ $\leq 50$ million euros.

For exposures in default, capital requirements $(K)$ are determined as follows (Basel Committee on Banking Supervision, 2006):

$$
K=\operatorname{Max}\left\{0 ;\left(L G D-E L_{B E}\right)\right\}
$$

where $E L_{B E}$ is the bank's best estimate of the expected loss for exposure in the default status.

Assessing the probability of default as a multiyear average of one-year default rates for each rating category of debtors is the first step in quantifying and assessing credit risk in the RBI approach and is the key aspect of banking regulation (Cardone-Riportella, Trujilo-Ponce \& Briozzo, 2011).

In the next part of the paper, the way how Z-score models can be used to estimate the probability of default is shown.

\section{THE APPLICATION OF THE CREDIT SCORING MODEL FOR ESTIMATING THE PROBABILITY OF THE DEFAULT STATUS}

The development of relevant models for quantifying the probability of the default status is the subject matter of numerous modern studies, many of them using logistic regression or logit regression, as well as discriminant analysis, which allows us to make a distinction between high- and low-risk borrowers. The following section provides an overview of some of these studies.

\section{Literature Review}

E. Altman and G. Sabato (2005) investigate the effects of applying the RBI approach on banks' capital requirements for exposures to small and mediumsized enterprises in the United States, Italy, and Australia. Using logistic regression on data obtained from over 2,000 U.S. companies (with the sales of less than $\$ 65$ million) in the period from 1994 to 2002, they developed a one-year bankruptcy prediction model. Taking into account the rules of the international agreement on bank capital (Basel Capital Accord) for small and medium-sized enterprises, they examined the ability of the model to lower capital requirements.

Based on the previous study, C. Cardone-Riportella, A. Trujilo-Ponce and A. Briozzo (2011) analyze 24 financial indicators in the year before bankruptcy and, using logistic regression, they develop a special model for estimating the one-year probability of the nonpayment of small and medium-sized enterprises for Spanish firms. They also examine the impact of the Internal Ratings-Based approach (IRB) on a bank's 
capital requirements in the portfolios of Spanish SMEs.

O. M. Dănilă (2012) deals with the application of credit scoring in order to quantify the probability of the bankruptcy of bank clients in Romania, highlighting the Z-score model and Moody's KMV EDF RiskCalc Model. Also referring to the paper written by E. Altman and G. Sabato (2005), logistic regression is used to estimate the probability of bankruptcy on the example of the 2,800 small and medium-sized enterprises that went bankrupt within 12 months.

Based on the unique set of data on the loans granted to German small and medium-sized enterprises, P. Behr and A. Güttler (2007) apply the logistics trend so as to assess the credit scoring model, the aim of which is to enable small and medium-sized enterprises to assess the expected probability of default. According to the authors, banks lack adequate incentives to increase the transparency of the credit risk measurement process, as their superiority in having customer information gives them an advantage over competing banks.

E. Altman, M. Esentato and G. Sabato (2018) point to the problems of information asymmetry in the financing of small and medium-sized enterprises by issuing bonds (in Italy, the SME bond market is known as "mini-bonds"). In order to achieve the required transparency of risk assessment, the authors of this study develop a model for assessing the creditworthiness of Italian small and medium-sized enterprises based on logistic regression and test it on the companies that issued mini-bonds. To assess the probability of the occurrence of the default status, they use the so-called Bond Rating Equivalents (BRE) and Mortality Rate Approach, which will be explained later.

Based on the above research, the next part of the paper deals with the assessment of the probability of the occurrence of the default status of small and medium-sized enterprises.

\section{A Methodological Approach to Estimating the Probability of Bankruptcy by Using the Z-Score Model}

In this part of the paper, the way how the well-known Altman Z-Score model can be used for the purpose of estimating the probability of the occurrence of the default status is presented. The process involves the following three steps:

- determining credit scores for a new debt or for the existing debt,

- determining the so-called Capital market risk equivalents - most often bond rating equivalents (BRE),

- assessing the probability of the default status by determining the "mortality rate" or by using the average probability of the default of the companies published by credit rating agencies.

To create the Z-Score model, E. Altman (1968) used the discriminant function that transforms individual variables into a single discriminant score, or the $Z$ value:

$Z=V_{1} X_{1}+V_{2} X_{2}+V_{n} X_{n}$

where:

$V_{1^{\prime}} V_{2^{\prime}} V_{n}=$ the discriminant coefficients, and

$X_{1}, X_{2}, X_{n}=$ the independent variables.

Having applied discriminant analysis, E. Altman obtained the following linear equation based on the five financial indicators: liquidity, profitability, indebtedness, solvency and the sales activity:

$Z=1.2 X_{1}+1.4 X_{2}+3.3 X_{3}+0.6 X_{4}+1.0 X_{5}$

where:

$X_{1}=$ net working capital/total assets,

net working capital $=$ (current assets - short-term liabilities)

$X_{2}=$ retained earnings/total assets,

$X_{3}=$ earnings before interest and taxes/total assets,

$X_{4}=$ the market value of equity/total liabilities, and

$X_{5}=$ sales/total assets. 
The classification of whether a corporate entity will go bankrupt or not was made based on the results of determining the "safe" zone for the values of the $\mathrm{Z}$ indicators greater than 2.99, and the "financial problems" zone or the "bankruptcy" zone ("Distress") for the $\mathrm{Z}$ values of less than 1.81, between which there was the middle, "Gray" zone, which included the companies whose $\mathrm{Z}$ value was within the range from 1.81 to $2.99(1.81<Z<2.99)$. The zones were selected by Altman based on the results obtained on a sample of 66 manufacturing firms ( 33 in the bankrupt group and 33 in the nonbankrupt group) observed in the period from 1946 to 1965. E. Altman (2018) emphasizes the fact that the model shows high accuracy in predicting bankruptcy (between $82 \%$ and $94 \%$ ) one year after the assessment based on the original data, as well as on the data pertaining to 86 problematic companies in the period from 1969 to 1975, the 110 companies that went bankrupt in the period from 1976 to 1995, and 120 companies in the period from 1997 to 1999.

E. Altman (1983) revised the Z-Score so as to adjust it for the assessment of non-joint stock companies. Said revision included changes in the indicator X4, so that it was determined on the basis of the book value of capital instead of being determined based on the market, which enabled the inclusion of non-joint stock companies whose shares were not listed on the stock exchange. This change is particularly important in the markets where the market price is not considered as the good indicator of value due to the market size, the low trading volume, or illiquidity. The Z'-score model was developed, which took the following form:

$$
Z^{\prime}=0.717 X_{1}+0.847 X_{2}+3.107 X_{3}+0.420 X_{4}+0.998 X_{5}
$$

If the value of $Z^{\prime}$ is greater than 2.9, the company is in the "safe" zone, and if it is less than 1.23, the company is in the "financial problems" zone.

E. Altman, J. Hartzell and M. Peck (1995) conducted another revision of the model applied to emerging market corporations, which could be used to assess the ratings of private manufacturing and non-manufacturing companies in developed and emerging markets. In addition to the previous change made in the indicator $X_{4^{\prime}}$ which in that version of the model was not determined based on the market value of capital, but based on the book value of capital, in this version of the model they excluded the indicator $X_{5^{\prime}}$ because it was particularly sensitive to differences in certain manufacturing and non-manufacturing sectors when retail or service companies were compared with certain manufacturing companies.

As a result, they obtained the Z"-score model in the form of the following linear equation:

$Z^{\prime \prime}=3.25+6.56 X_{1}+3.26 X_{2}+6.72 X_{3}+1.05 X_{4}$

A Z"-score less than 4.35 indicates the fact that the company is in the "financial problems" zone, and a $Z^{\prime \prime}$-score greater than 5.85 indicates the fact that the company is in the "safe" zone.

When calculating the Z"-score in emerging markets, E. Altman, J. Hartzell and M. Peck (1995) proposed that a constant $(+3.25)$ should be added in order to standardize the results, so that a score equal to or slightly below or above 0 would be equivalent to the situation in which the default status occurred, i.e. in the D rating category, in accordance with the Standard and Poor rating marks. The D rating is assigned when S\&P Global Ratings believe that bankruptcy will happen and that the debtor will not pay all or substantially all the amount of his obligations as they fall due.

E. Altman, A. Danovi and A. Falini (2013) applied the $Z^{\prime \prime}$-score model in order to predict the corporate failure of the Italian banks in which extraordinary administration was introduced. The model showed great accuracy in predicting bankruptcy (in as many as $95.5 \%$ of the cases) in the year preceding the declaration of bankruptcy. These results determined J. R. Chieng (2013) to apply this model to the banks of the Euro Area, and the results of the research showed that the Z"-score model was a reliable indicator of the failure of the banks in the Euro Area within five years before bankruptcy. However, as the author himself stated, this model might not be as precise in another industry or institution not operating in the Euro Area.

Table 1 shows the different rating categories according to the Standard and Poor average Z-scores, the average Z"-scores in emerging markets (Average EM Score), 
Table 1 The relationship between the results of the Z-score, the Standard and Poor ratings, and the probability of the default of companies in emerging markets

\begin{tabular}{l|ccccc}
\hline Zone & S\&P Rating & $\begin{array}{c}\text { The amount of } \\
\text { credit risk }\end{array}$ & $\begin{array}{c}\text { Average Z-Score } \\
1996-2001^{*}\end{array}$ & $\begin{array}{c}\text { Average Z"-score } \\
\text { in emerging } \\
\text { markets* }\end{array}$ & $\begin{array}{c}\text { The average probability of } \\
\text { the default of a company } \\
\text { during one year (1981- } \\
\text { 2019)** }\end{array}$ \\
\hline \multirow{5}{*}{ Safe } & AAA & minimal & 6.20 & 8.15 & $0.00 \%$ \\
& AA & very low & 4.73 & 7.30 & $0.00 \%$ \\
\multirow{3}{*}{ Gray } & A & low & 3.74 & 6.65 & $0.03 \%$ \\
\multirow{2}{*}{ Distress } & BBB & moderate & 2.81 & 5.85 & $0.12 \%$ \\
& BB & considerable & 2.38 & 4.95 & $0.53 \%$ \\
& B & high & 1.80 & 4.15 & $3.03 \%$ \\
& CCC & very high & 0.33 & 2.50 & $18.25 \%$ \\
\hline
\end{tabular}

Source: Altman, Hotchkiss \& Wang, 2019; Default, Transition and Recovery, 2019.

and the historical average cumulative probabilities of the default of companies during one year in emerging markets.

The bond rating equivalent allows Z-score models to be used to assess the probability of default. In the markets with a long history and a fairly large number of the rated bonds that have found themselves in the default status, Z-score results can be linked to their ratings and based on the updated databases of the so-called "static pools". S\&P rating agencies or dynamic-cohort rating agencies Moody's (Hamilton \& Cantor, 2006) obtain PD values over a period of time staring from the rating date. For the companies that are not rated, the results of the Z-score can be linked to the bond rating equivalent. Comparing the values of the Z-score results and S\&P ratings, E. Altman demonstrated a decline in the value of the Z-score results, which was most dominant in the companies with the AAA and AA ratings - the average Z-score decreased to 4.13 in 2013 from the high 5.20 in the period from 1996 to 2001, but it was even more significant for the companies with the single B rating the average Z-scores decreased from 1.87 in the period from 1992 to 1995 to 1.70 in 2017. These changes led to an increase in the Type II Error, i.e. the companies were classified into the bankruptcy zone without the occurrence of that; therefore, E. Altman proposed that the equivalent to the bond rating should be used instead of the limit 1.8 based on the original sample.

An alternative to the above-described approach is to use the E. Altman "Mortality Rates" approach based on the estimate of the expected bankruptcy rate from the original bond issuance date. E. Altman and H. J. Suggit (2000) also apply this concept to bank loans and estimate annual mortality rates and compare these results with the mortality rates of the publicly traded bonds during the sample period (1991-1996). Following this work, J. Fidrmuc, C. Hainz and A. Malesich (2007) set a Marginal Mortality Rate (MMR) for the 700 short-term loans granted to Slovakian small and medium-sized enterprises between January 2000 and June 2005.

The following analysis is focused on the application of the Z-score model in order to assess the probability of default, and it demonstrates the impact of this parameter on the assessment of credit risk within the Basel II concept.

\section{CREDIT RISK ASSESSMENT ON THE SELECTED SAMPLE OF SMES IN SERBIA}

The website of the Business Registers Agency, which provides information on the business entities 
registered within a certain group of the activities and a public information portal to promote transparency in conducting the bankruptcy proceedings of the Bankruptcy Trustee Licensing Agency was used as a source of necessary financial data on the small and medium-sized enterprises operating in the territory of the Republic of Serbia for the purpose of assessing credit risk.

Since the formation of the database of the necessary data required considerable manual work, our paper is limited to the analysis of the companies registered in accordance with the Statistical Office of the Republic of Serbia (Official Gazette of the RoS, no. 54/2010), whose activities imply the production of cocoa, chocolate and confectionery (Group 10.82).

In July 2020, a total of 39 companies were registered for the production of cocoa, chocolate and confectionery products with the Business Registers Agency (Group 10.82). As many as 13 bankruptcy proceedings of the companies registered in this group of activities were registered on the public information portal promoting transparency in conducting bankruptcy proceedings in the period from 2010 to July 2020.

As displayed on the website of the Register of Financial Statements that started operating within the Business Registers Agency on $1^{\text {st }}$ January 2010, starting from 2016, publicly available financial reports will be based on the three small and medium-sized companies in which bankruptcy proceedings were initiated in 2019 and 2020 and which had performed business activities in 2017 (namely Vekić Chocolate Ltd from Temerin, Tomaco Line Ltd from Leskovac, and Dunja Ltd from Belgrade). The sample of the companies that operated in 2020 consists of the randomly selected 10 small and medium-sized enterprises from this group of activities.

The goal of the following analysis is not only to check the accuracy of the Z-score model in predicting bankruptcy, but also to look at the financial health of this segment of the industry and demonstrate how Z-score results can be related to the equivalent of bond rating.

Given the fact that Z-score methods are based on accounting data, the accuracy of financial statements is extremely important. Therefore, it should be noted that one of the selected companies in bankruptcy is not subject to audit, and one received a qualified opinion in 2017. Also, only two of the selected 10 active companies were classified into the category of medium-sized legal entities and were subject to audit.

A comparative presentation of the capital and liabilities based on the long- and short-term bank loans of the selected companies in 2017 and 2018 indicates the presence of over-indebtedness in some companies and confirms the fact that loans from commercial banks are the most important external source of financing for small and medium-sized enterprises in this group in the Republic of Serbia (Figure 1).

Based on the balance sheets of the three companies in bankruptcy, it can be noticed that the two companies, namely Vekić Chocolate and Tomaco Line, borrowed long-term loans, and the largest part of the liabilities were liabilities to suppliers. Unlike these two companies, the company Dunja Ltd Belgrade did not have long-term credit arrears, and on $31^{\text {st }}$ December 2017, the short-term loan approved by Direktna banka JSC Kragujevac accounted for $79 \%$ of all the liabilities of the company. As far as active companies are concerned, these recorded an increase in credit indebtedness in 2018 compared to 2017, namely Paraćinka, Bg produkt 1996 and Kondiva, which are classified in the following analysis into the group of the companies with a high and very high credit risk.

Because the equivalent bond rating is not determined in the literature on the basis of the results of the $Z^{\prime}$ score model, the values of the Z"'-score were first calculated, for whose calculation the book value of capital was also used. However, the results of the Z"score model obtained based on the annual financial statements for the year 2017 showed that the company Dunja, which was in bankruptcy, had operated in the safe zone, and based on the equivalent bond rating the company was assigned the BBB rating, so it is believed that this indicator cannot be considered as reliable for assessing the credit risk of the SMEs belonging to the Activity Group 10.82 in the observed period. A decision was brought to analyze the results of the application of the Z-score model if the book value of capital was included instead of the market value 


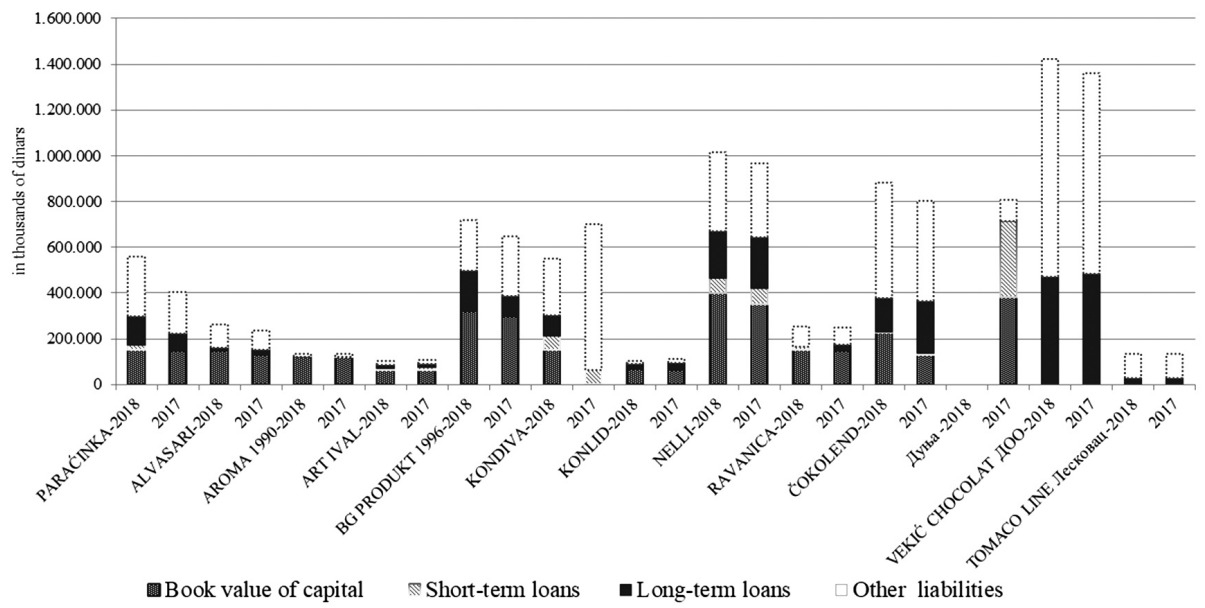

Figure 1 The ratio of the capital and liabilities of the selected companies in 2017 and 2018

Source: Serbian Business Registers Agency, 2020.

of capital and if that was compared with the results of the application of the Z'-score model, because it involved the use of the book value of capital. The results of the application of the Z-score, Z'-score, and Z'-score models for the years 2017 and 2018 are shown in the following (Table 2 and Table 3).

The application of the results of the Z-score models shows that, in 2017, a total of six companies were classified in the category of the companies with financial problems based on the bond rating equivalent of the three companies classified into the group assigned the $\mathrm{D}$ rating, and the other three companies with the CCC rating. All the three companies in which bankruptcy was initiated in 2019 and 2020 are classified into the "financial problems" zone.

In the period of two years after the assessment, the companies classified into the safe zone did not went bankrupt, while the three companies classified into the "financial problems" zone did not go bankrupt.

The following part of the paper shows the extent to which the allocation of SMEs into the category of exposure to individuals affects the capital adequacy requirements. As in E. Altman and G. Sabato (2005), the LGD of $45 \%$ is used, as suggested for the basic approach, based on the internal rating for the older claims that are either unsecured or secured by unrecognized collateral. According to (OECD, 2020), the share of the loans granted to small and mediumsized enterprises in Serbia that required collateral in 2018 was $53.1 \%$. To calculate the cumulative weighted capital requirement for credit risk, the previously presented average probabilities of the default of the company during one year estimated by the S\&P rating agency were used and that the company's share in each rating category was identical to our sample was assumed.

When calculating a capital requirement for credit risk when an SME is classified into the category of exposure to companies, the effective maturity of the credit exposure is assumed to be three years (Table, 4). In 2018, the long-term loans accounted for $77.2 \%$ of the total loans granted to small and medium-sized enterprises in Serbia, and for about $87 \%$ in the selected sample of companies.

Increasing effective maturity by one year in the given example would increase capital requirements by about $2.75 \%$ (Table 5).

The preliminary results show that, if SMEs are classified into the category of exposure to natural persons, a capital requirement will amount to 3.96\% according to the assumptions, whereas if SMEs are 
Table 2 The results of the application of the Z-score, Z'-score and Z"-score models for 2017

\begin{tabular}{|c|c|c|c|c|c|c|c|c|c|c|}
\hline Name & Z"-score & Rating & PD & Zone & Z'-score & Zone & Z-score & Rating & PD & Zone \\
\hline AROMA 1990 & 16.67 & AAA & $0.00 \%$ & Safe & 5.33 & Safe & 7.36 & AAA & $0.00 \%$ & Safe \\
\hline CONLID & 10.62 & AAA & $0.00 \%$ & Safe & 2.95 & Safe & 3.78 & A & $0.03 \%$ & Safe \\
\hline ALVASARI & 10.24 & AAA & $0.00 \%$ & Safe & 3.01 & Safe & 3.78 & A & $0.03 \%$ & Safe \\
\hline ART IVAL & 8.24 & AAA & $0.00 \%$ & Safe & 2.54 & Gray & 3.24 & BBB & $0.12 \%$ & Safe \\
\hline $\begin{array}{l}\text { BG PRODUCT } \\
1996\end{array}$ & 5.72 & BB & $0.53 \%$ & Gray & 1.85 & Gray & 2.19 & B & $3.03 \%$ & Gray \\
\hline PARAĆINKA & 5.17 & BB & $0.53 \%$ & Gray & 1.60 & Gray & 1.82 & B & $3.03 \%$ & Gray \\
\hline RAVANICA & 4.58 & B & $3.03 \%$ & Gray & 1.37 & Gray & 1.80 & B & $3.03 \%$ & Gray \\
\hline NELLI & 5.31 & BB & $0.53 \%$ & Gray & 1.46 & Gray & 1.76 & $\mathrm{CCC}$ & $18.25 \%$ & Distress \\
\hline DUNJA * & 5.93 & BBB & $0.12 \%$ & Safe & 1.13 & Distress & 1.44 & $\mathrm{CCC}$ & $18.25 \%$ & Distress \\
\hline CHOCOLATE & 3.27 & $\mathrm{CCC}$ & $18.25 \%$ & Distress & 1.03 & Distress & 1.05 & $\mathrm{CCC}$ & $18.25 \%$ & Distress \\
\hline $\begin{array}{l}\text { VEKIĆ CHOCOLAT } \\
\text { doo * }\end{array}$ & 1.92 & D & & Distress & 0.19 & Distress & 0.11 & D & & Distress \\
\hline $\begin{array}{l}\text { TOMACO LINE } \\
\text { Leskovac* }\end{array}$ & 1.13 & D & & Distress & 0.01 & Distress & 0.00 & D & & Distress \\
\hline KONDIVA & -5.30 & D & & Distress & -1.36 & Distress & -1.93 & D & & Distress \\
\hline
\end{tabular}

* Bankrupt company

Source: Authors

Table 3 The results of the application of the Z-score, Z'-score and Z"'-score models for 2018

\begin{tabular}{|c|c|c|c|c|c|c|c|c|c|c|}
\hline Name & Z"-score & Rating & PD & Zone & Z'-score & Zone & Z-score & Rating & PD & Zone \\
\hline AROMA 1990 & 16.78 & AAA & $0.00 \%$ & Safe & 5.27 & Safe & 7.33 & AAA & $0.00 \%$ & Safe \\
\hline CONLID & 10.73 & AAA & $0.00 \%$ & Safe & 3.34 & Safe & 4.27 & A & $0.03 \%$ & Safe \\
\hline ALVASARI & 10.32 & AAA & $0.00 \%$ & Safe & 2.94 & Safe & 3.74 & A & $0.03 \%$ & Safe \\
\hline ART IVAL & 8.52 & AAA & $0.00 \%$ & Safe & 2.51 & Gray & 3.24 & BBB & $0.12 \%$ & Safe \\
\hline $\begin{array}{l}\text { BG PRODUCT } \\
1996\end{array}$ & 6.76 & A & $0.03 \%$ & Safe & 1.93 & Gray & 2.34 & B & $3.03 \%$ & Gray \\
\hline RAVANICA & 5.62 & BB & $0.53 \%$ & Gray & 1.72 & Gray & 2.18 & B & $3.03 \%$ & Gray \\
\hline NELLI & 5.72 & BB & $0.53 \%$ & Gray & 1.77 & Gray & 2.12 & B & $3.03 \%$ & Gray \\
\hline KONDIVA & 4.99 & BB & $0.53 \%$ & Gray & 1.72 & Gray & 1.89 & B & $3.03 \%$ & Gray \\
\hline CHOCOLATE & 4.61 & B & $3.03 \%$ & Gray & 0.95 & Distress & 1.64 & $\mathrm{CCC}$ & $18.25 \%$ & Distress \\
\hline PARAĆINKA & 3.38 & $\mathrm{CCC}$ & $18.25 \%$ & Distress & 1.50 & Gray & 1.02 & $\mathrm{CCC}$ & $18.25 \%$ & Distress \\
\hline $\begin{array}{l}\text { TOMACO LINE } \\
\text { Leskovac* }\end{array}$ & 2.03 & D & $100 \%$ & Distress & 0.02 & Distress & 0.04 & D & $100 \%$ & Distress \\
\hline $\begin{array}{l}\text { VEKIĆ CHOCOLAT } \\
\text { doo * } \\
\text { DUNJA* }\end{array}$ & 1.66 & D & $100 \%$ & Distress & -0.07 & Distress & -0.18 & D & $100 \%$ & Distress \\
\hline
\end{tabular}

* Bankrupt company

Source: Authors 
Table 4 The capital requirement for exposure to individuals

\begin{tabular}{l|cccccc}
\hline Rating & PD & LCD & R & K & Weight & Total weighted K \\
\hline AAA & $0.00 \%$ & $45 \%$ & 0.15995 & 0.00022 & 0.1 & $0.00 \%$ \\
AA & $0.00 \%$ & $45 \%$ & 0.15995 & 0.00022 & 0 & $0.00 \%$ \\
A & $0.03 \%$ & $45 \%$ & 0.15864 & 0.00377 & 0.2 & $0.08 \%$ \\
BBB & $0.12 \%$ & $45 \%$ & 0.15465 & 0.01081 & 0.1 & $0.19 \%$ \\
BB & $0.53 \%$ & $45 \%$ & 0.13799 & 0.02835 & 0 & $0.19 \%$ \\
B & $3.03 \%$ & $45 \%$ & 0.07502 & 0.05332 & 0.4 & $2.32 \%$ \\
CCC & $18.25 \%$ & $45 \%$ & 0.03022 & 0.08183 & 0.2 & $3.96 \%$ \\
\hline
\end{tabular}

Source: Authors

Table 5 The capital requirement for exposure to companies

\begin{tabular}{l|cccccccc}
\hline Rating & PD & LCD & R & b & M & K & Weight & Total weighted K \\
\hline AAA & $0.00 \%$ & $45 \%$ & 0.20438 & 0.56130 & 3 & 0.00325 & 0.1 & $0.03 \%$ \\
AA & $0.00 \%$ & $45 \%$ & 0.20438 & 0.56130 & 3 & 0.00325 & 0 & $0.03 \%$ \\
A & $0.03 \%$ & $45 \%$ & 0.20266 & 0.31683 & 3 & 0.01093 & 0.2 & $0.25 \%$ \\
BBB & $0.12 \%$ & $45 \%$ & 0.19746 & 0.23711 & 3 & 0.02382 & 0.1 & $0.49 \%$ \\
BB & $0.53 \%$ & $45 \%$ & 0.17651 & 0.16449 & 3 & 0.05033 & 0 & $0.49 \%$ \\
B & $3.03 \%$ & $45 \%$ & 0.11082 & 0.09614 & 3 & 0.08650 & 0.4 & $3.95 \%$ \\
CCC & $18.25 \%$ & $45 \%$ & 0.08446 & 0.04482 & 3 & 0.16095 & 0.2 & $7.17 \%$ \\
\hline
\end{tabular}

Source: Authors

classified into the category of exposure to companies, a capital requirement will be 1.81 times as high if the effective maturity of such credit exposure is three years.

\section{CONCLUSION}

The presented results of the research study show that, to some extent, Z-score models can detect the companies in which bankruptcy may occur in the two years after an assessment, but they cannot be considered as reliable for assessing the probability of the bankruptcy of the small and medium-sized enterprises engaged in the production of cocoa, chocolate and confectionery in Serbia. When interpreting the obtained results, we should bear in mind the fact that Z-score models are based on data from the past and that the environment in which
SMEs operate has recently been exposed to dramatic changes. In addition to the above-said, one of the most important limitations of the research study is the fact that, at the time of writing the paper, only financial statements starting from 2016 to 2018 were publicly available on the website of the Register of Financial Statements, for the reason of which fact it was impossible to cover the research study for a longer period of time and thus provide a more reliable assessment and the development of a more adequate model by increasing the sample size.

The contribution made by this paper reflects in the fact that, regardless of the above-mentioned data limitations and the limitations regarding the applied method, a comparative overview of the companies and their ranking in accordance with the assessed credit risk is provided, simultaneously giving a more transparent insight into the state of this segment of 
the industry as well. This research study is based on the hypothesis that an increase in the transparency of the credit risk measurement process is in the interest of SMEs and that a greater transparency is also in the interest of all creditors, primarily banks, because untimely noticed problems might have unforeseeable consequences for the entire banking sector, depending on the concentration of the loans granted to SMEs. As in P. Behr and A. Güttler (2007), it is considered that increasing the transparency of the credit risk measurement process and reducing the asymmetry of information will provide borrowers with the ability to negotiate loan terms based on more information and that it will also increase the likelihood of a successful change of one bank for another that provides better terms. It will also create the opportunities for using alternative sources of financing, thus expanding the scope of financing opportunities for companies.

Given the fact that the results of the research study show that Z-score models cannot be considered as reliable for assessing the probability of the bankruptcy of small and medium-sized enterprises, directions for further research will be focused on the development of the credit scoring models adapted to the market of the small and medium-sized enterprises of the Republic of Serbia, which will enable greater transparency in credit risk assessment.

\section{REFERENCES}

Altman, E. (1968). Financial ratios, discriminant analysis and the prediction of corporate bankruptcy. The Journal of Finance 23(4), 589-609. doi.org/10.1111/j.1540-6261.1968. tb00843.x

Altman, E. (1983). Corporate Financial Distress. New York, NY: John Wiley \& Sons.

Altman, E., Hartzell, J., \& Peck, M. (1995). A Scoring System for Emerging Market Corporate Bonds. New York, NY: Salomon Brothers High.

Altman, E., \& Suggitt, H. J. (2000). Default rates in the syndicated bank loan market: A mortality analysis. Journal of Banking and Finance, 24(1-2), 229-253. doi:10.1016/S03784266(99)00058-8
Altman, E., \& Sabato, G. (2005). Effects of the New Basel capital accord on bank capital requirements for SMEs. Journal of Financial Services Research, 28(1), 15-42. doi.org/10.1007/ s10693-005-4355-5

Altman, E., Danovi, A., \& Falini, A. (2013). Z-Score models' application to Italian companies subject to extraordinary administration. Journal of Applied Finance, 23(1), 128-137.

Altman, E. (2018). A Fifty-Year Retrospective on Credit Risk Models, the Altman Z -Score Family of Models and their Applications to Financial Markets and Managerial Strategies. Journal of Credit Risk, 14(4), 1-34. doi:10.21314/ JCR.2018.243

Altman, E., Esentato, M., \& Sabato, G. (2018). Assessing the credit worthiness of Italian SMEs and mini-bond issuers. Global Finance Journal, 43(C). doi: 10.1016/j. gfj.2018.09.003

Altman, E., Hotchkiss, E., \& Wang, W. (2019). Corporate Financial Distress, Restructuring, and Bankruptcy. New Jersey, NJ: Jon Wiley \& Sons.

Basel Committee on Banking Supervision. (2006). International Convergence of Capital Measurement and Capital Standards. Retrieved Juni 24, 2020, from https:// www.bis.org/publ/bcbs128b.pdf

Behr, P., \& Güttler, A. (2007). Credit risk assessment and relationship lending: An empirical analysis of German small and medium-sized enterprises. Journal of Small Business Management, 45(2), 194-213. doi.org/10.1111/j.1540627X.2007.00209.x

Cardone-Riportella, C., Trujilo-Ponce, A., \& Briozzo, A. (2011). What do Basel capital accords mean for SMEs? Working Paper 10, Department of Economics of the University Carlos III of Madrid Business Economic.

Chieng, J. R. (2013). Verifying the Validity of Altman's Z Score as a Predictor of Bank Failures in the case of the Eurozone. Submitted to the National College of Ireland.

Dănilă, O. M. (2012). Credit risk assessment under Basel accords. Theoretical and Applied Economics, 19(3), 77-90.

Default, Transition, and Recovery. (2019). Annual Global Corporate Default And Rating Transition Study. Retrieved Juli 3, 2020, from https://www.spglobal.com/ratings/en/ research/articles/200429-default-transition-and-recovery2019-annual-global-corporate-default-and-rating-transitionstudy-11444862 
Erić, D. (2003). Finansijska tržišta i instrumenti. Beograd, RS: Čigoja štampa.

Erić, D. D., Beraha, A., Đuričin, O. S., Kecman, Đ. N., \& Jakišić, B. B. (2012). Finansiranje malih i srednjih preduzeća u Srbiji. Beograd, RS: Institut ekonomskih nauka i Privredna komora Srbije.

Ernst \& Young Global Limited (EY). (2019). EY Entrepreneurial Barometer. Retrieved Juli 7, 2020, from https://www.ey.com/ Publication/vwLUAssets/EY_Preduzetni\%C4\%8Dki barometar_2019/\$File/EY\%20Preduzetni\%C4\%8Dki\% 20barometar\% 202019.pdf

Fidrmuc, J., Hainz, C., \& Malesich, A. (2007). Default Rates in the Loan Market for SMEs. Discussion Papers in Economics, University of Munich, Department of Economics. https:// www.researchgate.net/publication/5164114_Default_Rates_ in_the_Loan_Market_for_SMEs.

Hamilton, D., \& Cantor, R. (2006). Measuring Corporate Default Rates. Moody's Investors Service, Global Credit Research, Retrieved Juni, 24, 2020, from https://www.moodys.com/ sites/products/defaultresearch /2006200000425249.pdf
Hurlin, C., Leymarie, J., \& Patin, A. (2018). Loss functions for loss given default model comparison. European Journal of Operational Research, 268(1), 48-360, doi:10.1016/j. ejor.2018.01.020

Mishkin, F. S., \& Eakins, S. G. (2006). Financial Markets and Institutions. Boston, M: Addison Wesley.

National Bank of Serbia (NBS). (2020). Lista podobnih agencija za rejting. Retrieved Juli 7, 2020, from https://www.nbs.rs/ internet/latinica/55/55_5/ rejting_agencije.pdf

OECD. (2020). Financing SMEs and Entrepreneurs 2020: An OECD Scoreboard. OECD Publishing, Paris. Retrieved Juli, 7, 2020, from https://doi.org/10.1787/061fe03d-en

Serbian Business Registers Agency. (2020). Business Registers Agency. Retrieved Juli 3, 2020, from https://www.apr.gov.rs/

Statistical Office of the Republic of Serbia. (2020). Official Gazette of the Republic of Serbia. no. 54/2010.

Received on $28^{\text {th }}$ September 2020, after revision, accepted for publication on $18^{\text {th }}$ December 2020. Published online on $25^{\text {th }}$ December 2020.

Mirela Mitrasevic is employed at the Faculty of Business Economics, University of East Sarajevo, where she is engaged as an associate professor of Financial Mathematics, Insurance and Risk Management in banks and insurance companies in full-time studies and Financial Mathematical Analysis and Insurance Analysis in master studies. She is a member of the Association of Actuaries of the Republic of Srpska and the Association of Actuaries of Serbia.

Snezana Bardarova is Assistant profesor at the Faculty of Tourism and Business Logistics, Department of Business Logistics and Business Administration at University Goce Delcev, Stip, Republic of North Macedonia. She is Assistant profesor from the field of economics of enterprises and economics of public sector. Her professional occupation are economics of enterprises, management and entrepreneurship. 


\title{
MERENJE RIZIKA POZAJMLJIVANJA MALIM I SREDNJIM PREDUZEĆIMA U REPUBLICI SRBIJI U SVETLU SAVREMENIH BANKARSKIH REGULATIVA
}

\author{
Mirela Mitrašević 1 i Snežana Bardarova² \\ ${ }^{1}$ Faculty of Business Economics, Bijeljina, University of East Sarajevo, Bosnia and Herzegovina \\ ${ }^{2}$ Faculty of Tourism and Business logistics, Gevgelija, University Goce Delcev, Stip, Republic of \\ North Macedonia
}

Predmet ovog rada je merenje rizika pozajmljivanja malim i srednjih preduzećima (MSP), sa aspekta postojećih bankarskih regulativa. U radu se polazi od hipoteze da bi povećanje transparentnosti procesa merenja kreditnog rizika omogućilo blagovremeno otkrivanje problema i ostavilo prostor za preduzimanje neophodnih radnji za upravljanje malim i srednjim preduzećima, kao i svim poveriocima, i da bi, na taj način, MSP dobila priliku da se obezbede povoljniji izvori finansiranja. U istraživanju je korišćen Altmanov Z-skor model za procenu verovatnoće, da se preduzeća neće pridržavati svojih ugovornih obaveza i za rangiranje privrednih društava. Rezultati primene Z-skor modela ukazuju na činjenicu da se tim modelima, u izvesnoj meri, mogu otkriti ona privredna društva koja će u periodu od dve godine nakon izvršene procene možda proglasiti stečaj, s jedne strane, ali da se oni ne mogu smatrati pouzdanim kada je u pitanju procena verovatnoće da će doći proglašenje stečaja u malim i srednjim preduzećima u Republici Srbiji.

Ključne reči: finansiranje MSP, kreditni rizik, zahtevi kapitala, kreditno bodovanje, ekvivalent za ocenjivanje obveznica

JEL Classification: G21, G28 